\title{
ZPRÁVY
}

\section{Závěry z výzkumu restrukturalizace strojírenských podniků}

Současná zásadní transformace společnosti se do ekonomiky promítá kromě jiného v podobě restrukturalizace. Mění se celospolečenská struktura národního hospodářství, privatizace a zahraniční kapitál vstupují do jednotlivých podniků. Ty se musí adaptovat na zcela nové podmínky a hledat takové výrobní programy, které budou mít reálnou šanci realizovat se na trhu.

Restrukturalizační procesy jsou spojeny se změnami techniky a technologie a jako takové probíhaly poměrně intenzívně ve vybraných průmyslových podnicích už v 80 . letech. Měly svou sociální dimenzi, která se stala předmětem výzkumu zejména sociologů z resortních výzkumných ústavi. Pak byly v roce 1989 zpracovány prípadové studie, které na různých místech a v různých typech podniků analyzovaly strukturální změny probíhající $\mathrm{v}$ rámci technického rozvoje.

V Praze byla provedena analýza komplexní inovace koncernového podniku TOS Hostivař, která měla charakter automatizace integrovaných výrobních úseků, dopravy a rízení, a na vzorovém projektu se podíleli i sociologové. Návrh zahrnul v rámci vnitropodnikové organizace i řízení sociální, chápané jako personální a sociální rozvoj ve čtyřech oblastech:

- rrízení sociálních procesů; těžiště této oblasti spočívá ve zpracování a aplikaci metod a technik sociálního řizení, v řízení konkrétních sociálních procesů včetně získávání pracovníků pro komplexní inovaci;
- ergonomické řešení pracovišt; zaměřuje se na řešení problémů člověka $v$ pracovním procesu $\mathrm{z}$ hlediska pracovního prostř́edí $\mathrm{v}$ širokém slova smyslu a $\mathrm{z}$ hlediska sociálně psychologických faktorů pracovního procesu;

- príprava a výběr pracovníků; hlavním problémem této oblasti je identifikace změn ve struktuře pracovníků, stanovení nároků nových, případně velmi změněných funkcí a profesí a zpracování systémů prípravy pracovníkü;

- hmotná a morální stimulace; těžiště této oblasti spočívá $\mathrm{v}$ modifikaci současného systému hmotné stimulace tak, aby odpovídal celkovému principu řešení inovace, oživení soustavy morálních podnětů a sjednocení působnosti obou stránek stimulace.

Předpokladem pro rozvoj sociálního systému je provedení sociální analýzy pro adekvátní a dostatečně konkrétní zaměření všech navrhovaných opatření. Analýza odpovídá na otázku, jaké jsou sociální nároky připravovaných změn a jaké předpoklady je naplnit má inovaci realizující organizace. Výsledky sociální analýzy umožňují kvalifikovaně zpracovat program sociálního rozvoje ve všech jeho částech, a to na základě poznatků o - individuálních a skupinových předpokladech pracovníki̊ $\mathrm{k}$ řešení a realizaci změn

- sociálním klimatu organizace, jeho přednostech a slabých stránkách

- charakteru a úrovni sociálního řizení ze strany vrcholového vedení 
- účasti široké fronty pracujících na rízení a rozhodování

- postojích pracovníků $\mathrm{k}$ předpokládaným změnám

- stavu pracovního a životního prostředí.

Návrh personálního a sociální rozvoje, zpracovaný $\mathrm{v}$ rámci výzkumného úkolu TOS Hostivař, předpokládal na základě výsledků analýzy zpracování programu získávání pracovníků pro podporu komplexní inovace, což mělo podpořit vytvoření přiznivého, proinovačniho sociálního klimatu.

Optimálně pojaté získávání pracovníkủ pro komplexní inovaci je závislé na připravenosti organizace na modernizaci a rekonstrukci, a to nejen po věcné stránce, ale především po stránce sociální. Rozhodující pritom je sociální rízení, tj. úroveň a formy vedení lidí a pracovních kolektivů. Není-li přiměřené předpokládané inovaci, je nutno nejdříve zlepšit sociální řízení. Stejnĕ tak je tomu pokud jde o analogickou situaci, napr. $\mathrm{v}$ oblasti koncepčního ř́zení $\mathrm{z}$ vrcholového vedení podniku.

Přislušná analýza a následná opatření začínají zcela jednoznačně od vrcholového vedení inovující organizace. Postoje vrcholového vedení, podniku či závodu rozhoduji o relevantních postojích v celé vertikále řízení. Jak vrcholové vedení organizace podporuje prípravu, řešení a realizaci modernizace či rekonstrukce, tak budou požadovat a podporovat participaci nižších stupňủ rízeni - provozu, dílny, pracoviště.

Vzory proinovačního chování se na základě výzkumů a zkušeností zcela odvíjejí od vrcholového vedení organizace. To jim vtiskuje rozhodující charakter a dynamiku.

Program získávání pracovníků pro komplexní inovaci tedy především spočívá v optimalizaci systému práce vrcholového vedení organizace a v systému práce s lidmi v organizaci. Konkrétně je pracovníky možné získat především programem zlepšení pracovních podmínek vyvolávajících nespokojenost. To tvoří reciproční stránky získávání pracovníků. Organizace chce od lidí zajistit chod něčeho nového, co je spojeno $s$ jistým zatížením, a proto je nutné jim nabídnout jako kompenzaci určitá zlepšení, výhody apod.

Cestou pro získání lidí, pro řešení a realizaci komplexni inovace je vytvoření promyšleného systému forem účasti pracovníků organizace na př́pravě a realizaci změn, inovačních záměrů aj., např. pracovních komisí a týmů, poradních orgánů, závazkového hnutí, vyhlašování tematických úkoli̊ apod. Za takové situace není např. informování pracovníků nějakým vážnějším problémem, protože se vlastně uskutečňuje během pracovního procesu $\mathrm{v}$ pružných organizačních strukturách.

Získáváním pracovníků pro inovaci je nutné přkeknat nezájem, nebo dokonce $\mathrm{i}$ odpor $\mathrm{k}$ pr̆ipravovaným změnám. Lidé se často brání, odporují změnám, protože $\mathrm{z}$ nich mají oprávněné obavy; že naruši dosavadní styl jejich práce, vybudované vzájemné mezilidské vztahy, postavení, prestiž, finanční ohodnocení apod.

Navrhovaná analýza a program získávání pracovníků pro podporu inovačních záměrů byl v TOS Hostivař realizován pouze částečně. Proběhlo školení vrcholového vedení a odborná školení dalších pracovníků, témata o komplexní inovaci byla zařazena do různých typů školení. Většinou však šlo o obecné informace bez aktivní účasti jednotlivých pracovníků na inovačním procesu. Zejména skutečnost, že vrcholové vedení podniku nebylo dostatečně identifikováno se záměry inovace, se negativně projevila jak $\mathrm{v}$ průběhu modernizace, tak $\mathrm{v}$ jejím konečném efektu.

Strukturální změna ve formě komplexní inovace prinesla v TOS Hostivař významné výsledky, ale nedosáhla celkového předpokládaného cíle. Příčiny a dílčí sociální souvislosti jsou naznačeny $\mathrm{v}$ předcházejících částech. Za základní podmínky úspěšnosti strukturálních změn pokládáme dodržení koncepčnosti, komplexnosti a důslednosti $v$ jejich přípravě a realizaci.

Koncepčnost znamená v této souvislosti odpovědný výběr podniku pro strukturální změnu, podložený technologickou, ekonomickou a sociální analýzou. Vybraný podnik by měl mít dobrý a perspektivní výrobní program a možnost pružně reagovat na změny trhu. Návrh na inovaci by měl vycházet $\mathrm{z}$ jeho vnitřní potřeby a měl by souznit s celkovým sociálním klimatem, pozitivně nakloněným progresívním změnám. Vrcholové vedení takového podniku by mělo být vnitř- 
ně identifikováno s potřebou inovace schopné participovat tvořivým způsobem na její přípravě a realizaci, nést potřebná rizika a jasně vymezit cíle i způsoby jejich dosažení.

Komplexnost předpokládá řešení technických, technologických, ekonomických a sociálních problémů ne vedle sebe, ale ve vzájemné integraci. Propojení jednotlivých systémů nemůže být formální, žádný z nich není realizován odděleně a nedostatky jednoho se promítnou do fungování ostatních. Podcenění sociální problematiky a liknavost $\mathrm{v}$ jejím řešení se vrátí v podobě sociálního napětí, nezájmu nebo dokonce odporu vůči novým technologím, které $\mathrm{v}$ jednotlivých př́padech vyústilo až do úmyslného poškození nových technických zařizení. Špatně fungující hmotněenergetický systém s vysokou poruchovostí posiluje negativní postoje $\mathrm{k}$ inovacím a prohlubuje skepsi pracovníki. Ekonomický a rrídicí systém, který kupř. včas a vhodným zpủsobem nevyřešil hmotnou stimulaci pracovníků, narušuje fungování ostatních systémů. Komplexnost znamená společné řešení, bez preference a s respektováním sociálního dopadu každého ekonomického a technického opatření. Zaručit takovou komplexnost by mělo zpracování sociálního programu souběžně s technologickým a ekonomickým projektem.

Dưslednost navazuje na předcházející a projevuje se jako dovedení projektů do konečné realizace, a to zase ve všech zminěných oblastech. $\mathrm{V}$ průběhu strukturální změny dochází zákonitě $\mathrm{k}$ únavě a následným tendencím urychlit proces tím, že se vynechají ty části, které se zdánlivě nezdají nutné a nesouvisejí přímo s výrobním procesem. Podobně lze pozorovat snahu o vyšší ekonomickou efektivnost u voluntaristických rozhodnutí, sledujících pouze okamžitý efekt bez zvážení dalších možných důsledků. Nedotaženost projektů prí realizaci způsobuje, že se nedostaví ani očekávané výsledky.

$\mathrm{V}$ prípadě TOS Hostivař nebyla bezezbytku dodržena ani jedna $\mathrm{z}$ uvedených podmínek, výběrem podniku počínaje a barevným řešením výrobních úsekủ konče. Při hodnocení komplexni inovace závodu se však setkáváme se stanoviskem, že hlavním důvodem neúplných výsledki je nedostatek pracovníki̊ a nedotaženi sociální přípravy, což platí pouze částečně. Domnívat se, že „zlatým kličem" $\mathrm{k}$ odstranění všech nedostatků mohla být sociální sféra, je jednostranné a scestné. I kdyby byla v plném rozsahu uskutečněna opatř̌ní $\mathrm{k}$ získávání pracovníků a jejich podpory proinovačních záměri̊n, nemohlo to přinést očekávané výsledky $\mathrm{v}$ plném rozsahu. Nejlepším argumentem pro inovaci je totiž fungujicí hmotněenergetická soustava a její zřejmá ekonomická výhodnost. Jestliže tyto faktory chybí, nebo se dokonce realizují změny proti „zdravému rozumu“, potom žádná sebelepší príprava sociálního systému, která ostatně neprobíhá izolovaně, ale $\mathrm{v}$ konkrétním společenskoekonomickém klimatu, nemůže tyto nedostatky zakrýt.

I za těchto okolností však mohl důsledně provedený sociální projekt přinést zmúrnění konfliktů při realizaci inovací, zejména pokud by se včas podařilo prosadit adekvátní sociální řízení, stmelit a motivovat vrcholové vedení, pripravit pracovníky reálně také na nedostatky ve fungování automatizovaných výrobních a rídicích systémů a přinést i očividné výhody kupř. celkovým zlepšením pracovního prostředí, dokonalejši sociální péčí a dobrou perspektivou pro všechny pracovníky závodu.

Při celkovém hodnocení provedené strukturální změny je zároveň zřejmé, že výše uvedené podmínky nemohly být $\mathrm{v}$ tehdejší společenskoekonomické situaci (léta 1978-85) v potřebné míre dodrženy. $\mathrm{V}$ podmínkách direktivního ríizení bylo možné komplexní inovace realizovat pouze výjimečně a v omezeném rozsahu, pomocí mimořádných opatření a $\mathrm{s}$ využitím mimořádných forem zainteresovanosti.

Ze zkušenosti z TOS Hostivař a dalších podniků, ve kterých inovace automatizačního typu proběhly v menším rozsahu, vyplývají závěry použitelné při strukturálních změnách obdobného typu.

Tvorba nezbytného sociálního programu má nezastupitelné místo $\mathrm{v}$ celkové př́pravě na strukturální změnu. Předpokladem odpovídající formulace sociálního a personálního rozvoje je objektivní identifikace sociální situace podniku, ze které pak vyplynou hlavní směry sociotechnických opatření cílených na jednotlivé sociální a profesní skupiny. 
Poznatky $\mathrm{z}$ komplexní inovace v TOS Hostivař dokazují, že problematika aktivizace lidského činitele a vytvoření objektivních i subjektivních podmínek pro jeho participaci na připravě a realizaci změn je neopomenutelným předpokladem požadovaného konečného efektu. Sociální program kromě toho, že zajištuje sociální a perso- nální rozvoj jako součást strukturální změny, zároveň pozitivně působí na ekonomickou efektivitu: snižuje konfliktnost celého období, urychluje adaptaci pracovníků na novou technologii, a prispívá tak ke splnění výrobních a ekonomických cílů.

Jitka Havlová

\section{Sociologie času - nová odvětvová sociologie?}

Je až zarážející, jak málo se ve standardně pojatých výkladech a učebnicích základů sociologie setkáváme s tak elementární kategorií, jakou je čas. Ještě počátkem 70 . let bylo možné se značnou mírou oprávněnosti konstatovat, že problém času není v sociologii dostatečně výrazně vnímán (určitou výjimku představovala pouze tematika volného a pracovního času). Tato situace se ovšem záhy výrazně změnila. V 80 . letech zájem o fenomén času nebývale vzrostl, a to zejména $\mathrm{v}$ německy mluvících zemích. Téma, do té doby namnoze opomíjené, se v polovině 80 . let stává záležitostí téměř módní. Objevuje se řada statí, monografií a několik sborníků, konají se odborné semináře a sympozia, zaznamenáváme snahy o interdisciplinární prístup. $\mathrm{O}$ tom, že výzkum $\mathrm{v}$ dané oblasti doznal značný rozmach, svědčí nepřimo i to, že sociologie času (Zeitsoziologie) je dnes již chápána jako jakási samostatná konkrétní sociologická disciplína - „odvětvová sociologie".

I přes jistou novost a módnost jde ovšem o disciplínu s vlastní, a to nikoliv zanedbatelnou historii, $v$ níž se pochopitelně projevují také vazby na dominantní proudy filozofického myšlení. Vliv Husserlových podnětů na fenomenologicky orientovaný směr, tedy především na Schützovy a Luckmannovy analýzy jednání, v nichž čas a časové rozvrhování hrají významnou roli, není patmě třeba nijak zvlášt připomínat. Heidegger v tomto směru inspiroval méně, jeho vliv nacházíme především v tzv. existencialistické sociologii (E. Tyryakian). Kličovou roli zde však patrně sehrály ideje H. Bergsona (zejména jeho pojetí "durée" a rozlišování vnitřního, subjektivního času vědomí a objektivního, měřitelného času vnějšího světa), jejichž odraz nalézáme u Huber- ta, Mausse a Halbwachse (Durkheimova škola), ale také u Schütze, Sorokina či Luhmanna.

Pokud jde o klasiky sociologického myšlení, je třeba $\mathrm{v}$ dané souvislosti zmínit $\mathrm{v}$ prvé řadě $\mathrm{E}$. Durkheima (čas má sociální charakter, je podobně jako náboženství sociálně konstruován), G. Simmela (čas je důležitým mechanismem zespolečenštění) a G. H. Meada (specifická struktura lidského jednání je předpokladem konstituce času). Z dalších významných postav dějin sociologie je nutné vzpomenout především P. A. Sorokina (odlišení sociálního, respektive sociokulturního a tzv. kvantitativního času), G. Gurwitche (zdůraznění multiplicity a heterogenity sociálních časů) a W. E. Moora (zkoumání časových dimenzí na různých sociálních úrovních), pokud jde o současné autority, nelze opomenout $P$. Bourdieua a A. Giddense.

$V$ německé oblasti je to především Niklas Luhmann, v jehož dílech přichází v průběhu 60 . a 70 . let problematika času nezřídka ke slovu, byt mnohdy pouze $\mathrm{v}$ podobě okrajových poznámek. Čas je podle Luhmanna vytváren v procesu intersubjektivní konstituce, jako jakési, pro jednotlivce společné kontinuum časových bodů, v nichž něco trvá a něco se mění. Vedle pojmu čas použivá Luhmann také pojem chronologie. Zatímco čas může nabývat nejrozličnějších forem, chronologie je jednodimenzionální. Vzhledem k mnohosti časů plní chronologie tedy cosi jako integrativní úlohu. Relativně značná pozornost je věnována času a jeho vztahu $\mathrm{k}$ systémovým strukturám $\mathrm{v}$ Luhmannově pozdějším díle Soziale Systeme (1984).

$\mathrm{Za}$ jistým způsobem průkopnickou je $\mathrm{v}$ německé sociologii času považována kniha Wernera Bergmanna Die Zeitstrukturen sozialer Sys- 